\title{
First Hollow Stem: A Critical Wheat Growth Stage for Dual-purpose Producers
}

Jeff Edwards

Small Grains Extension Specialist

\section{Gerald Horn}

Beef Cattle Nutritionist

Oklahoma farmers sow approximately six million acres of wheat annually. Anywhere from 40 percent to 60 percent of these acres are grazed by cattle during the winter. Producers wishing to graze wheat and subsequently harvest grain must decide when to remove cattle from wheat pasture. Grazing too long will reduce wheat yields, but removing cattle too early will reduce profit potential of the stocker cattle enterprise. Finding the correct balance between these two factors has been the subject of investigation for decades.

As early as the 1930s, Kansas State University researchers published Extension bulletins indicating that cattle should be removed from wheat pasture by jointing. Oklahoma State University researchers investigated the issue further in the early 1990 s and found that if profitability of the overall wheat stocker cattle enterprise was the primary goal, removing cattle from wheat pasture by jointing was too late. They identified first hollow stem as the optimal wheat growth stage for removing cattle from wheat pasture. The purpose of this fact sheet is to explain why first hollow stem is the best time to remove cattle from wheat pasture, provide details on how to identify first hollow stem, and discuss some of the environmental and physiological factors that determine when first hollow stem occurs.

\section{Importance of First Hollow Stem}

Wheat intended for grazing is generally sown in early September. Due to this earlier-than-optimal sowing date, grazed wheat will generally yield less than nongrazed wheat sown in mid-October. Since dual-purpose wheat producers are already dealing with reduced yield potential, as compared to a grain-only system, it is extremely important to protect the yield potential present by removing cattle from wheat pasture prior to first hollow stem. As shown in Figure 1, the average grain yield reduction from grazing wheat pasture past first hollow stem depends on several factors.

Studies conducted at the Wheat Pasture Research Unit near Marshall during the early 1990 s and at Stillwater during the 2003 and 2005 crop years have shown that grazing past first hollow stem decreases grain yield by as much as five percent per day or as little as one percent per day. The amount of green leaf area left after grazing, for example, will significantly impact wheat recovery after grazing. Green leaf tissue is the factory that powers wheat growth. The more green leaf tissue left at grazing termination, the greater the yield potential. So wheat pasture that is not grazed as hard or that was not grazed
Oklahoma Cooperative Extension Fact Sheets are also available on our website at: http://osufacts.okstate.edu

during muddy conditions will recover from grazing more quickly than wheat that is grazed short or stomped into the ground.

Cool, wet conditions after cattle removal are favorable for wheat recovery. These environmental conditions allow the wheat plant extra time to regain some of the vegetative growth lost to grazing prior to switching to reproductive mode. So an additional two weeks of grazing past first hollow stem could cost the producer as little as 14 percent or as much as 58 percent of original yield potential. In most circumstances, the additional cattle weight gain from grazing past first hollow stem would not be sufficient to offset the loss in grain yield. To determine the economic impact of grazing past first hollow stem on your farm, consult the Oklahoma Grazeout Decision Maker program available at http://agecon.okstate.edu/faculty/publications/3443.xlsm

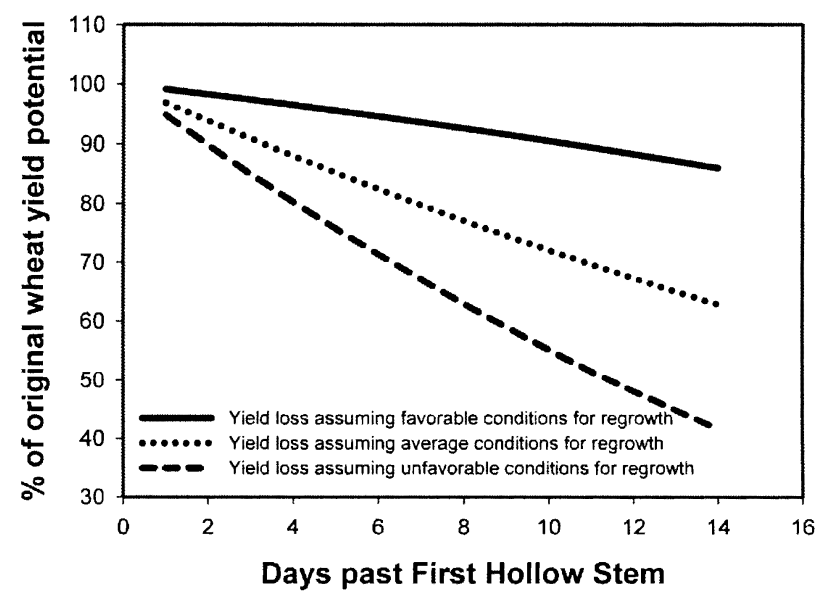

Figure 1. Grazing past first hollow stem has been shown to reduce grain yield by as much as five percent per day or as little as one percent per day. Factors such as variety, grazing intensity and environmental conditions will determine the actual yield penalty for grazing past first hollow stem. This figure shows the anticipated yield loss for grazing past first hollow stem given favorable (solid line), unfavorable (dashed line) and average (dotted line) conditions for wheat regrowth following grazing termination. 


\section{What Determines When First Hollow Stem Occurs?}

First hollow stem is affected by genetic and environmental factors. Varieties can differ by as much as three weeks in onset of first hollow stem, and later maturity varieties generally reach first hollow stem later. OSU researchers measure and record dates of first hollow stem of popular wheat varieties each year. These data are reported via the Plant and Soil Sciences Extension Newsletter (www.pss.okstate.edu/extension/newsletter).

Data are also used to classify varieties as either very early, early, medium, late or very late in occurrence of first hollow stem. These ratings can be found in Extension Fact Sheet PSS-2142 Wheat Variety Comparison. Dual-purpose producers are encouraged to select varieties that are rated as medium, late or very late in occurrence of first hollow stem.

Early-sown wheat will reach first hollow stem earlier than late-sown wheat. Moderate conditions during the winter months and adequate rainfall also promote earlier onset of first hollow stem. Due to the strong effects of planting date and environment, it is extremely difficult to accurately predict the onset of first hollow stem with weather data. So the most reliable method of determining first hollow stem is to check every field and check often.

\section{Checking for First Hollow Stem}

To check for first hollow stem, go to a nongrazed area and pull four to five plants. Plants must be dug up to check for hollow stem because much of the hollow stem present at this time is still below the soil surface. Hollow stem must be measured from a nongrazed area in the same field because grazing delays stem elongation and when first hollow stem occurs. Good places to find areas of nongrazed wheat are field corners or nongrazed areas just outside of the electric fence.

Select the largest tillers on the plants. Split the stems open lengthwise starting at the base. A sharp razor or box cutter will make this job easier. If there is $1.5 \mathrm{~cm}(5 / 8$ inch)

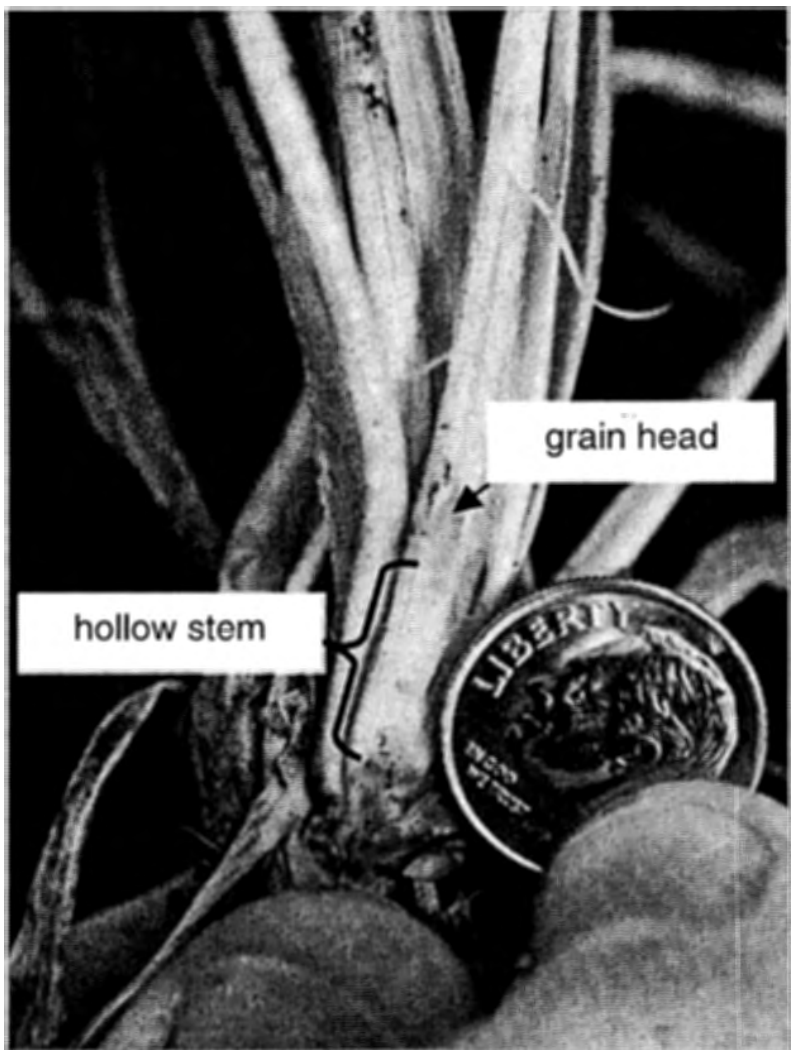

Figure 2. First hollow stem occurs when hollow stem equivalent to the diameter of a dime $(1.5 \mathrm{~cm})$ is present below the developing grain head.

of hollow stem below the developing wheat head (Figure 2), the wheat is at first hollow stem. Luckily, $1.5 \mathrm{~cm}$ is about the same as the diameter of a U.S. dime, making the dime a perfect measuring device for first hollow stem.

Oklahoma State University, in compliance with Title VI and VII of the Civil Rights Act of 1964, Executive Order 11246 as amended, Title IX of the Education Amendments of 1972, Americans with Disabilities Act of 1990, and other federal laws and regulations, does not discriminate on the basis of race, color, national origin, gender, age, religion, disability, or status as a veteran in any of its policies, practices, or procedures. This includes but is not limited to admissions, employment, financial aid. and educational services.

Issued in furtherance of Cooperative Extension work, acts of May 8 and June 30, 1914, in cooperation with the U.S. Department of Agriculture, Robert E. Whitson, Director of Cooperative Extension Service, Oklahoma State University, Stillwater, Oklahoma. This publication is printed and issued by Oklahoma State University as authorized by the Vice President, Dean, and Director o 